\title{
Final Design Report for the RH LLW Disposal Facility (RDF) Project
}

\author{
Project File: 31055
}

September 2015

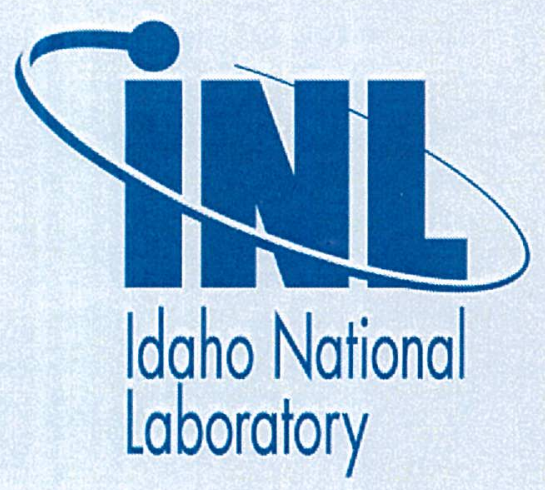

The INL is a U.S. Department of Energy National Laboratory operated by Battelle Energy Alliance 


\section{DISCLAIMER}

This information was prepared as an account of work sponsored by an agency of the U.S. Government. Neither the U.S. Government nor any agency thereof, nor any of their employees, makes any warranty, expressed or implied, or assumes any legal liability or responsibility for the accuracy, completeness, or usefulness, of any information, apparatus, product, or process disclosed, or represents that its use would not infringe privately owned rights. References herein to any specific commercial product, process, or service by trade name, trade mark, manufacturer, or otherwise, does not necessarily constitute or imply its endorsement, recommendation, or favoring by the U.S. Government or any agency thereof. The views and opinions of authors expressed herein do not necessarily state or reflect those of the U.S. Government or any agency thereof. 
INL/EXT-15-34701

Revision 3

\section{Final Design Report for the RH LLW Disposal Facility (RDF) Project}

Project File: 31055

September 2015

Idaho National Laboratory

Idaho Falls, Idaho 83415

http://www.inl.gov

Prepared for the

U.S. Department of Energy

Under DOE Idaho Operations Office

Contract DE-AC07-05ID14517 



\title{
Final Design Report for the RH LLW Disposal Facility (RDF) Project
}

\author{
INL/EXT-15-34701
}

Revision 3

Project File: 31055

September 2015
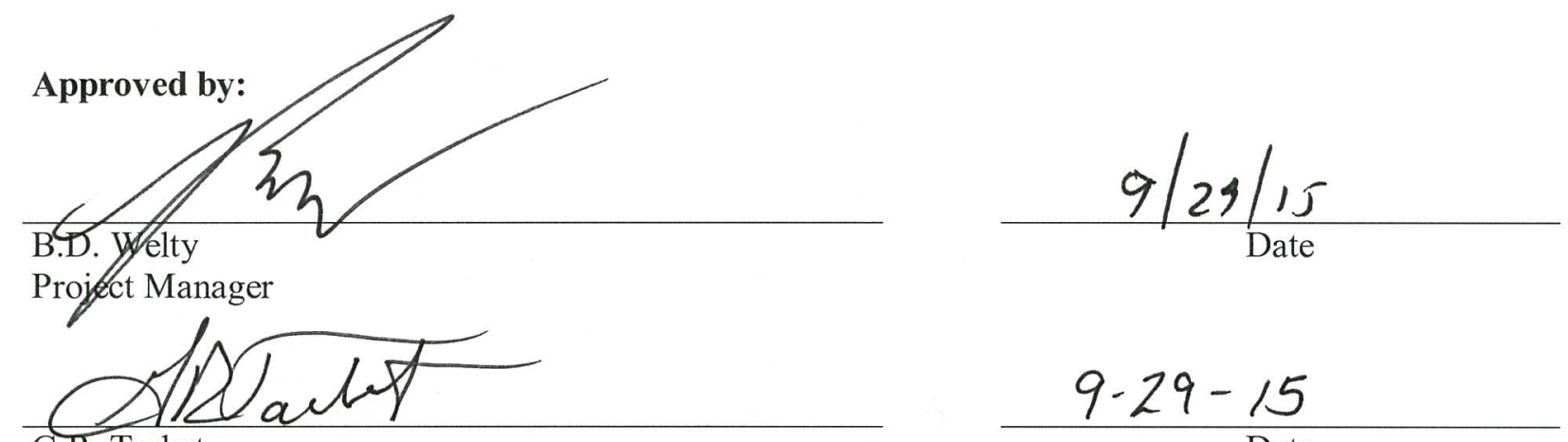

G.R. Tarbet

Design Authority

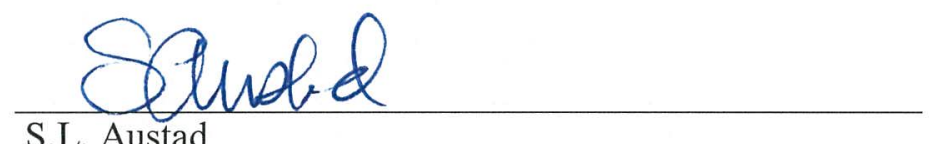

S.L. Austad

Project Engineer

$9-29-15$
$\frac{9.29 \cdot 15}{\text { Date }}$
Date




\section{CONTENTS}

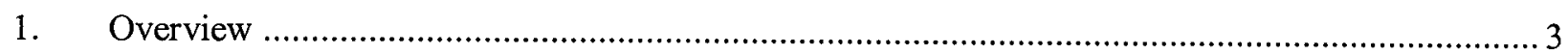

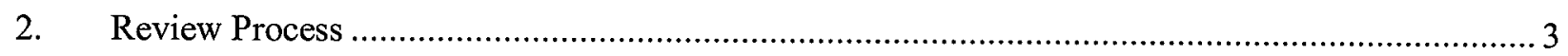

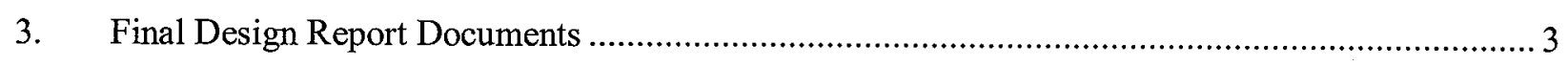

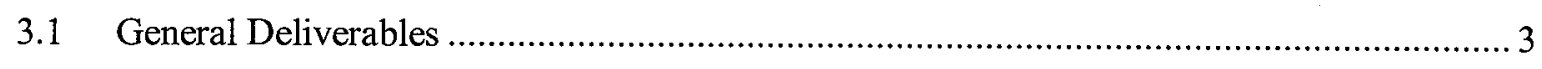

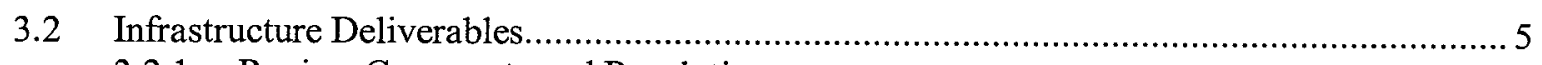

3.2.1 Review Comments and Resolutions ........................................................... 5

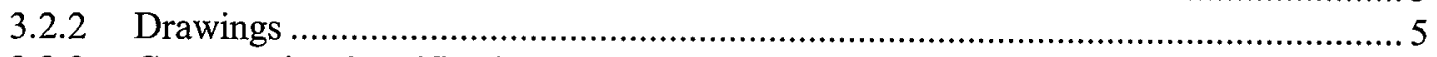

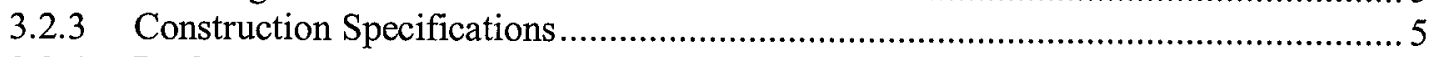

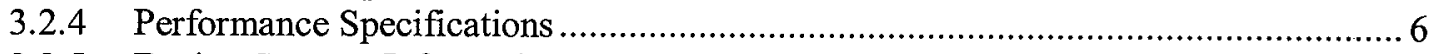

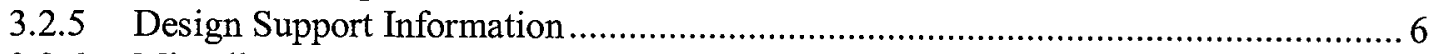

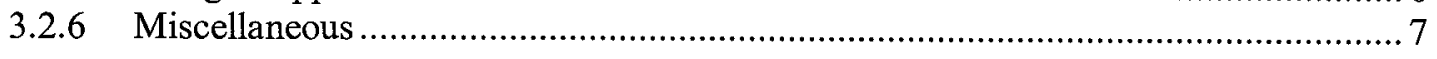

Vault System Deliverables.................................................................................. 7

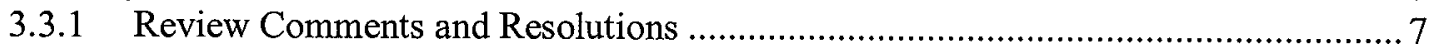

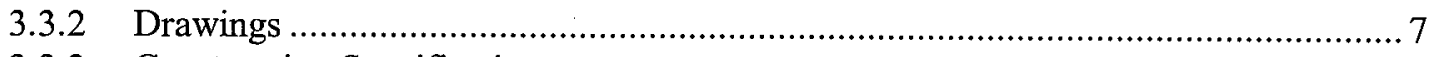

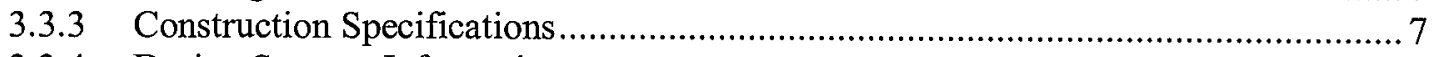

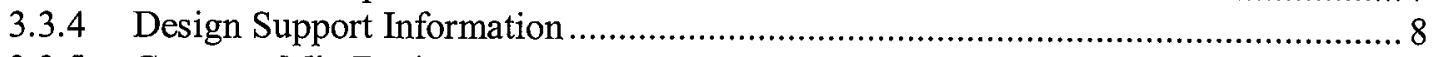

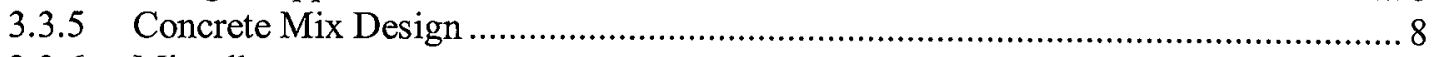

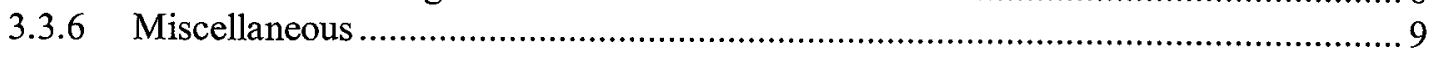

3.4 Ancillary Equipment Deliverables ........................................................................ 9

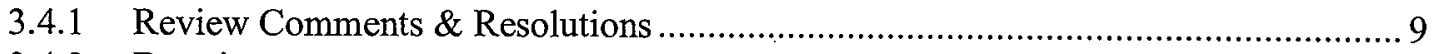

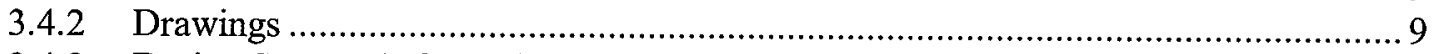

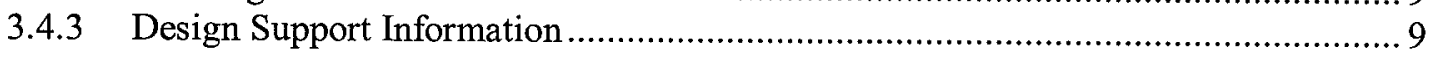

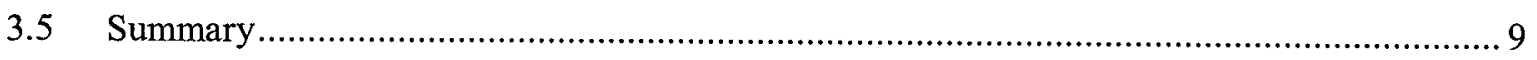




\section{FINAL DESIGN REPORT FOR THE RH LLW DISPOSAL FACILITY (RDF) PROJECT}

\section{Overview}

The RH LLW Disposal Facility (RDF) Project was designed by AREVA Federal Services (AFS) and the design process was managed by Battelle Energy Alliance (BEA) for the Department of Energy (DOE). The final design report for the RDF Project is a compilation of the documents and deliverables listed in Appendix A.

\section{Review Process}

A preliminary review (60\%) kickoff was held on November 3, 2014. The review was conducted using the BEA electronic change request (eCR) review system. Comments and resolutions for the preliminary review are included in eCR 627027 as "Review Number 1." A final design review (90\%) kickoff was held on December 10, 2014. The review process used the electronic eCR system to track comments, resolutions, and acceptance. DOE review of the design documentation was completed in March 2015, with authorization granted to proceed with infrastructure construction received March 26, 2015 (INL-15051). Several outstanding comments related to the vault system/cask-to-vault adapting structure design remained to be resolved. Following BEA review of updated vault system/cask-to-vault adapting structure design documentation, the vault system/cask-to-vault adapting structure design documentation was provided to DOE for review in July 2015. Comments from DOE were resolved and final submittal of the vault system/cask-to-vault adapting structure design documentation was completed in August 2015. DOE provided acceptance of the final design on September 4, 2015 (CCN 236501). BEA review documentation is maintained as project records in the eCR system. DOE comments and resolutions pertaining to the design review are maintained as project records.

\section{Final Design Report Documents}

Components of the final design are organized into four main sections: General, Infrastructure, Vault System, and Ancillary Equipment. Deliverables generally include drawings (DRAW); construction, fabrication, or performance specifications (SPC); vendor data schedules (VDS); calculations (CALC); and engineering information reports (EIR). Drawings and specifications are contractual documents between AFS and their construction subcontractors. Vendor data schedules provide instruction to the construction subcontractors for construction submittals such as product data, operational and maintenance manuals, etc. Calculations and EIRs provide design documentation information.

\subsection{General Deliverables}

Updated Project Definition Rating Index (PDRI): The PDRI was updated to reflect the status at CD $2 / 3$. The PDRI is maintained as a project record.

Construction Safety and Health Plan (TOC-732): Consists of the Subcontractor Requirements Manual (SRM) effective documents list, the 1000-, 2000-, and 8000- series requirements documents form the SRM. TOC-732 is maintained in EDMS.

Code of Record (INL/EXT-10-20044): The Code of Record was updated to reflect the actual scope of building types and materials used in the final design of the project. The code of record is maintained in EDMS.

Technical and Functional Requirements (TFR-483): This TFR documents the requirements to which the RDF was designed. The TFR is maintained in EDMS. 
Design-Build-Operate Performance Specification (SPC-1437): This performance specification, in addition to the TFR, documents the design requirements for the RDF. The performance specification is maintained in EDMS.

AFS Constructability Review: AFS coordinated a constructability review during the final design review. The review was conducted by Curt Ulferts, a construction consultant to AFS, and DelHur Industries, a teaming partner to AFS on the Project. The constructability review is maintained as a project record.

BEA Constructability Review (INL/EXT-15-34586): As a supplement to the AFS constructability report, BEA prepared an additional report to document the constructability review process that was implemented to insure that an effective constructability review was performed and that all requirements of DOE Order 413.3-9, "U.S. Department of Energy Project Review Guide for Capital Asset Projects," in regards to this process have been addressed for the Remote-Handled Low-Level Waste Disposal Facility (RDF). The BEA constructability review is maintained in EDMS.

Construction Plan: This plan describes the approach that AFS will employ to systematically plan for, construct and deliver the RDF, thus ensuring that the nuclear safety, quality, specifications, and contract requirements are satisfied in full. The construction plan is maintained as a project record.

LFRG Approval of Design-Build Approach: This letter, dated June 2012, was to formally summarize/document the LFRG's assessment of the current situation with respect to the existing Performance Assessment (PA) assumptions; and 2) outline our recommendations on how best to proceed in terms of LFRG collaboration as you work towards final facility design and construction. This document is maintained as a project record.

Preliminary Disposal Authorization Statement: Included is the Preliminary Disposal Authorization Statement for the INL RDF, dated April 2012. The PDAS is maintained as a project record.

Interim Cover Considerations Report: This white paper solicited input to ensure "all of the" potential impacts to operations and hydrologic and other issues associated with the interim cover were considered during the design review. The report is maintained as a project record.

Approved Construction Field Problems (CFPs) and Project Addendums: Included in the final design report are the approved CFPs that document any scope or requirement changes to the project contract documents and the project addendums. Approved CFPs are maintained as project records.

Startup Plan for the Remote Handled Low-Level Waste Disposal Facility (PLN-4967): This Startup Plan was developed to meet the requirements of Core Requirement 11 in DOE O 425.1D and follows the requirements for a startup plan identified in DOE-STD-3006-2010. The startup plan ensures management oversight to verify personnel performance, procedure viability, and equipment operability and is developed in accordance with Section 5.3 of DOE G 413.3-9 to confirm the ability of the facility to operate by assessing and verifying system performance, environmental permit conditions, and safety requirements. This plan is not a final design review deliverable and is not shown on the list in Appendix A. The Startup Plan is maintained on EDMS.

Contractor Operational Readiness Review (ORR) Plan of Action for the Remote Handled Low-Level Waste Disposal Facility (RDF) (PLN-4966): This draft document provides a Plan of Action (POA) to identify the applicable core requirements, describe the activities necessary to perform a Contractor Operational Readiness Review (CORR) and provide the criteria to verify readiness for the operation of the Remote-Handled (RH) Low-Level Waste (LLW) Disposal Facility. The Plan of Action is maintained in EDMS.

Remote Handled Low-Level Waste Facility (RDF) Transition to Operations Plan (PLN-4862): This document serves as the top-level implementation plan for transition of RDF from project/construction management to MFC Operations. The transition to operations plan is maintained in EDMS. 
Preliminary Fire Hazards Analysis (HAD-474): This report documents the Preliminary Fire Hazards Analysis (PFHA) for the Remote-Handled Low-Level Waste (RHLLW) Disposal Facility. The analysis in this FHA focuses on the low-level waste vault disposal area and does not address the support buildings and facilities located in the vicinity of this installation. The HAD is maintained in EDMS.

Commissioning Plan (RH-LLW-CP-00001): This document describes the transition from design to full operations and commissioning of the facilities. The Commissioning Plan, as developed by Areva Federal Services, is maintained as a project record.

\subsection{Infrastructure Deliverables}

The Project Infrastructure Deliverables include drawings; performance and construction specifications; calculations; engineering information records (EIRs); and vendor data schedules. The construction scope is divided into several different specification and drawing packages to complement the construction and bidding strategy. Stand-alone performance specifications will be used to procure the design and fabrication of the metal building systems for the Admin and Maintenance Buildings. Standalone performance specifications procure the design and installation of the fire alarm and fire sprinkler systems for the buildings. The scope of each document is described below.

\subsubsection{Review Comments and Resolutions}

Infrastructure Review Comments and Resolutions: Included are the BEA 60\% and 90\% review comments and resolutions as well as BEA reviews of incorporation of DOE's comments. BEA review documentation is maintained as project records in the eCR system. DOE comments and resolutions pertaining to the design review are maintained as project records.

\subsubsection{Drawings}

Infrastructure Drawings (788748 - 788912): The infrastructure drawings include the construction drawings for the installation of the buildings, site work including surface grading, sediment and erosion control, fencing, roadwork, monitoring wells, exterior lighting, and utilities. Drawings are maintained in EDMS.

\subsubsection{Construction Specifications}

Admin Building Construction Specification (RH LLW-SPC-00006 / SPC-1858): This specification accompanies the Infrastructure Drawings and includes the installation of the Admin Building, including architectural scope, HVAC, piping, plumbing fixtures, lighting, power distribution, lightning protection, and telecom/data. The specification is maintained in EDMS.

Maintenance Building Construction Specification (RH LLW-SPC-00007 / SPC-1859): This specification accompanies the Infrastructure Drawings and includes the installation of the Maintenance Building, including architectural and structural scope, HVAC, piping, plumbing fixtures, lighting, power distribution, lightning protection, and telecom/data. The specification is maintained in EDMS.

General Site Construction Specification (RH LLW-SPC-00008 / SPC-1860): This specification includes underground utilities (potable, sewer, fire water, electrical, telecom, data, and security), and site work (fencing, sidewalks and slabs, road work, surface grading). This specification will also accompany the Infrastructure Drawings. The specification is maintained in EDMS. 
Infrastructure Vendor Data Schedules: Included are the vendor data schedules for each specification. The specification is maintained in EDMS.

\subsubsection{Performance Specifications}

Admin Building Performance Specification (RH LLW-SPC-00001 / SPC-1861): The Admin Building structure is a pre-fabricated metal building system, comprised of rigid and portal frames enclosed with metal roofing and metal wall panels. The Admin Building will also have column-supported canopies for protecting exterior doorways. This specification includes design, analysis, shop drawings, and fabrication of the building metal building system, metal wall panels, and metal roofing. This specification does not include installation of the metal building system. The specification is maintained in EDMS.

Maintenance Building Performance Specification (RH LLW-SPC-00002 / SPC-1862): The Maintenance Building structure is a pre-fabricated metal building system, comprised of rigid and portal frames enclosed with metal roofing and metal wall panels. The Maintenance Building will also have column-supported canopies for protecting exterior doorways. This specification includes design, analysis, shop drawings, and fabrication of the building metal building system, metal wall panels, and metal roofing. This specification does not include installation of the metal building system. The specification is maintained in EDMS.

Fire Sprinkler Performance Specification (RH LLW-SPC-00003 / SPC-1863): Specification scope includes design, analysis, shop drawings, material, fabrication, and installation of the fire sprinkler system for the Maintenance Building. The specification is maintained in EDMS.

Fire Alarm Performance Specification (RH LLW-SPC-00004 / SPC-1864): This specification includes the requirements for design, shop drawings, material, and installation of the project fire alarm system. The specification is maintained in EDMS.

\subsubsection{Design Support Information}

Admin and Maintenance Buildings Foundation Calculations (RH LLW-CALC-00003 / ECAR2892): The calculations document the foundation design for both buildings, consisting of reinforced concrete footings, grade walls, and concrete slab-on-grade floors. The calculation is maintained in EDMS.

Electrical Calculation (RH LLW-CALC-00007 / ECAR-2812): This calculation documents the electrical distribution design established in the SKM modeling. The calculation is maintained in EDMS.

Mechanical Design Calculation (RH LLW-CALC-00008 / ECAR-2813): This document includes the sizing studies for the plumbing and HVAC systems for the new buildings and includes equipment data sheets for specific components used in the mechanical design. It also documents the building energy analyses, water usage documentation. The calculation is maintained in EDMS.

Civil Design Calculation (RH LLW-CALC-00010 / ECAR-2815): Calculations include roadway structural section design, vault yard layout design, and storm drain swale sizing. The calculation is maintained in EDMS.

Electrical Design Support Calculation (RH LLW-CALC-00011 / ECAR-2816): This calculation includes the lightning risk assessment for the Admin and Maintenance Buildings and photometric assessments for the building interiors and exteriors. The calculation is maintained in EDMS. 
Architectural Design Support Detail (RH LLW-EIR-00002 / TEV-2454): This engineering information record includes the building code analysis, daylighting analysis, and architectural energy conservation analysis. The EIR is maintained in EDMS.

SKM Electrical Design Model Results: The SKM native model files were transmitted to BEA and reviewed. Included in this deliverable are various analysis reports generated by BEA indicating that appropriate sizes and ratings have been used for breakers, fuses, cables, and transformers. The model results are maintained as a project record.

\subsubsection{Miscellaneous}

Utilities Tie-in Subsurface Investigation Report: Included in the subsurface investigation report for the utilities tie-in. The report is maintained as a project record.

USQ Evaluation for Utilities Tie-in Installation (ATR Complex-USQ-2014-539): A USQ has been performed for the tie-in to the ATR utility systems (fire water, potable water, power, etc.) The results of the evaluation are maintained as a project record.

Building Septic System Permit: Copies of the Septic System Permit application and approval forms have been provided for information. The permit application is maintained as a project record.

Infrastructure Construction Quality Verification Plan for the RH LLW Disposal Facility (RH LLW-EIR-00020 / PLN-4995): This document presents the infrastructure construction quality verification plans for the construction phase. This EIR is maintained in EDMS.

\subsection{Vault System Deliverables}

The vault system consists of the prefabricated, precast concrete vaults and vault plugs, and the vault backfill material. The precast vaults fabrication is performed in accordance with a vault fabrication construction specification and vault fabrication drawings. Installation is performed in accordance with the vault installation specifications and drawings.

\subsubsection{Review Comments and Resolutions}

Vault System Review Comments and Resolutions: Included is the BEA 90\% review as well as BEA reviews of incorporation of DOE's comments. BEA review documentation is maintained as project records in the eCR system. DOE comments and resolutions pertaining to the design review are maintained as project records.

\subsubsection{Drawings}

Vault Installation Drawings (RH LLW-DRAW-0001 - 0016 / 788643 - 788658): Scope of drawings package includes installation of prefabricated, precast vaults and vault backfill material. Drawings are maintained in EDMS.

Vault Fabrication Shop Drawings (Vendor Data): These drawings include the shop drawings to which the precast vaults will be fabricated. The fabrication shop drawings are maintained as a project record.

\subsubsection{Construction Specifications}

Construction Specification - Vault Fabrication (RH LLW-SPC-00005 / SPC-1857): Scope includes fabrication of the precast concrete vaults. The specification is maintained in EDMS.

Construction Specification - Vault Installation (RH LLW-SPC-00014 / SPC-1910): Scope includes installation of the precast concrete vaults and vault backfill materials, including pea gravel, controlled low-strength material, drainage course, and native alluvium. The specification is maintained in EDMS. 
Vault Vendor Data Schedules: Vendor data schedules, which summarize the required vendor data that the constructor is required to submit, are included for each vault specification. The vendor data schedules and submittals are maintained in the Vendor Data System.

\subsubsection{Design Support Information}

Vault System Design Description (SDD-410): Provides the system design description as required for Hazard Category 2 nuclear facility safety systems. SDDs identify the requirements associated with structures, systems, and components, explains why those requirements exist (that is, provides the bases for the requirements), and describes the features of the system design provided to meet those requirements. As part of a configuration management change control process, the SDD helps ensure consistency among the engineering requirements for systems, the actual installed physical configuration, and the associated documentation. The SDD is maintained in EDMS.

Vault System Structural Design (RH LLW-CALC-00001 / ECAR-2810): The purpose of this calculation is to document the structural design of the RH-LLW pre-cast concrete disposal vaults for the required dead, live, and seismic loads including code-driven combinations thereof. The calculation is maintained in EDMS.

Vault System Minimum Reinforcement and Lifting Lug Design (RH LLW-CALC-00005 / ECAR-2744): This set of calculations documents the detailed design of the precast concrete RH-LLW Disposal Vault System including minimum reinforcement and lifting lug design. The calculation is maintained in EDMS.

Vault Plug and CVAS Shielding Analysis (RH LLW-CALC-00006 / ECAR-2747): This document provides shielding calculations for the Remote Handled Low Level Waste (RHLLW). The calculation is maintained in EDMS.

\subsubsection{Concrete Mix Design}

Vault Concrete Safety-Related Test Plan (RH LLW-TEST-00001 / PLN-4955): This test plan provides the requirements for testing safety related characteristics of the concrete mix design provided in AFS Document RH LLW-EIR-00001, Vault Concrete Mix Design. The mix tested was developed in accordance with BEA Specification SPC-1437. The mix design was tested to ensure safety-related parameters are provided to support the vault plug design and shielding calculations. The test plan is maintained in EDMS.

Vault Concrete Durability Test Plan (RH LLW-TEST-00002 / PLN-4867): This test plan provides the requirements for testing the Concrete Mix Design provided in AFS Document RH LLW-EIR-00001, RH LLW Vault Concrete Mix Design. The mix tested was developed in accordance with BEA Specification SPC-1437. The mix design was tested to provide parameters to support strength and durability requirements for the vault components. The test plan is maintained in EDMS.

Vault Concrete Compliance Test Plan (RH LLW-TEST-00003 / PLN-4956): This plan is applicable to the precast concrete for the vault components including the CVASs. The test requirements provided in this document will be used for preparation of detailed test and inspection procedures. The test plan is maintained in EDMS.

Vault Concrete Mix Design Report (RH LLW-EIR-00001 / PLN-4953): This document documents the precast vault concrete mix design. The EIR is maintained in EDMS.

Vault Concrete Safety-Related Design Parameters (RH LLW-EIR-00013 / PLN-4954): This document discusses the Safety Related parameters associated with vault concrete and provides 
the safety-related test results. The concrete durability parameters are provided in RH LLWEIR-00014, Vault Concrete Durability Report. The EIR is maintained in EDMS.

Vault Concrete Selection Report (RH LLW-EIR-00014 / PLN-4952): The purpose of this evaluation is to provide the explanation for selection of the concrete mix designs to be used for the RH LLW precast concrete disposal vaults. The EIR is maintained in EDMS.

Vault Hydraulic and Concrete Performance Analysis: This document provides quantitative assessments of vault area hydraulic and concrete performance for precast concrete vault components. The analyses are provided to evaluate the final vault area and concrete design against the requirements of the Design-Build-Operate Performance Specification (SPC-1437, 2011). The analysis is maintained as a project record.

\subsubsection{Miscellaneous}

Vault Array Summary Table (RH LLW-EIR-00015 / TEV-2559): This table is an updated version of the vault scope table provided in the TFR. This EIR is maintained in EDMS.

Vault and Cask-to-Vault Adapting Structures (CVAS) Fabrication Quality Verification Plan (RH LLW-EIR-00021 / PLN-4957): This document describes the vault and Cask-to-Vault Adapting Structure (CVAS) fabrication quality verification plan. This EIR is maintained in EDMS.

Vault Installation Quality Verification Plan (RH LLW-EIR-00022 / PLN-4994): This document describes the vault installation quality verification plan. This EIR is maintained in EDMS.

\subsection{Ancillary Equipment Deliverables}

\subsubsection{Review Comments \& Resolutions}

Ancillary Equipment Review Comments and Resolutions: Included is the BEA 90\% review as well as BEA reviews of incorporation of DOE's comments. BEA review documentation is maintained as project records in the $\mathrm{eCR}$ system. DOE comments and resolutions pertaining to the design review are maintained as project records.

\subsubsection{Drawings}

Ancillary Equipment Drawings (791350 - 791353): Includes CVAS drawings for the HFEF-5 and Modified FTC casks, and the arrangement and alignment guide drawings for the NuPac 14-210L cask. These drawings are maintained in EDMS.

\subsubsection{Design Support Information}

Seismic Stability Evaluation of the RH LLW Casks (RH LLW-CALC-00013 / ECAR-2878):

This calculation serves as an evaluation of the seismic stability of the fire RDF casks including HFEF-5, Modified FTC, Large Concept Cask, NuPac 14-210L, and 55-ton casks. This calculation is maintained in EDMS.

AREVA Crane Analysis Report and BEA Recommendation: This report provides an analysis of alternatives to the existing Manitowoc $3900 \mathrm{~W}$ crane. Included is the BEA letter summarizing the recommendation for the preferred alternative to the Manitowoc crane to support RDF operations. The crane analysis is maintained as a project record.

\subsection{Summary}

Facility performance compliance: The design meets the requirements as specified in the T\&FR 483 and the SPC-1437 as verified by internal BEA design reviews and DOE design review. 
Constructability: The constructability of the facility was verified through issuance of subcontractor and BEA constructability reviews. Constructability of the facility infrastructure, the vault system, and the ancillary equipment addressed herein was reviewed and assessed through extensive design reviews performed by the subcontractor and the engineer of record, by BEA and by DOE. The design has been verified as documented through engineer of record professional engineer stamps, BEA approval of design documentation, and DOE acceptance of design documentation.

Code of Record Compliance: The final design, as delineated herein, complies with the established Code of Record (INL/EXT-10-20044).

Integration of the final design and the Preliminary Documented Safety Analysis. The design review process ensured that the final design and the PDSA are fully integrated. The final design supports the analysis and conclusions documented in PDSA-419. 
Appendix A

\section{RH LLW Disposal Facility Project Final Design Package}




\section{RH LLW Disposal Project Final Design Package}

\begin{tabular}{|c|c|c|c|c|}
\hline Deliverable & Rev. & Folder & AREVA Document \# & (if applicable) \\
\hline \multicolumn{5}{|l|}{ General } \\
\hline $\begin{array}{l}\text { Updated Project Definition Rating Index } \\
\text { (PDRI) }\end{array}$ & $\mathrm{N} / \mathrm{A}$ & 11-General\A-PDRI & N/A & N/A \\
\hline $\begin{array}{l}\text { Construction Safety \& Health Plan (site } \\
\text { SRM) }\end{array}$ & $\mathrm{N} / \mathrm{A}$ & \1-General\B-Construction Safety_Health Plan & N/A & TOC-732 \\
\hline Code of Record Update & 7 & \1-General\C-Code of Record & N/A & INL/EXT-10-20044 \\
\hline $\begin{array}{l}\text { Technical and Functional Requirements } \\
\text { Update }\end{array}$ & 5 & \1-General\D-TFR & N/A & TFR-483 \\
\hline $\begin{array}{l}\text { Design-Build-Operate Performance } \\
\text { Specification }\end{array}$ & 0 & 11-General\E-Design Building Specification & N/A & SPC-1437 \\
\hline AFS Constructability Review & N/A & 11-GeneralF-Constructability Review & $\mathrm{N} / \mathrm{A}$ & $\mathrm{N} / \mathrm{A}$ \\
\hline BEA Constructability Review & 0 & 11-GenerallF-BEA Constructability Review & N/A & INL/EXT-15-34586 \\
\hline Construction Plan & 0 & \1-General|G-Construction Plan & RH- LLW-CNP-0001 & $\mathrm{N} / \mathrm{A}$ \\
\hline LFRG Approval of Design-Build Approach & N/A & \1-General\H-LFRG Approval & N/A & N/A \\
\hline $\begin{array}{l}\text { Preliminary Disposal Authorization } \\
\text { Statement }\end{array}$ & N/A & \1-General\I-Prelim Disposal Auth & $\mathrm{N} / \mathrm{A}$ & $\mathrm{N} / \mathrm{A}$ \\
\hline Interim Cover Considerations Report & & \1-General J-Interim Cover Considerations & $\mathrm{N} / \mathrm{A}$ & N/A \\
\hline Contract Addendums & $\mathrm{N} / \mathrm{A}$ & $\backslash 1$-General\K-CFPs \& Addendums & $\mathrm{N} / \mathrm{A}$ & $\mathrm{N} / \mathrm{A}$ \\
\hline $\begin{array}{l}\text { Approved Construction Field Problems } \\
\text { (CFPs) }\end{array}$ & N/A & \1-General\K-CFPs \& Addendums & N/A & $\mathrm{N} / \mathrm{A}$ \\
\hline $\begin{array}{l}\text { Startup Plan for the Remote Handled Low- } \\
\text { Level Waste Disposal Facility }\end{array}$ & 0 & |1-General $\mid L-S t a r t u p ~ P l a n$ & $\mathrm{~N} / \mathrm{A}$ & PLN-4967 \\
\hline $\begin{array}{l}\text { Contractor Operational Readiness Review } \\
\text { (ORR) Plan of Action for the Remote } \\
\text { Handled Low-Level Waste Disposal } \\
\text { Facility (RDF) }\end{array}$ & DRAFT & \1-General\M-Contractor ORR Plan & $\mathrm{N} / \mathrm{A}$ & PLN-4966 \\
\hline $\begin{array}{l}\text { Remote Handled Low-Level Waste Facility } \\
\text { (RDF) Transition to Operations Plan }\end{array}$ & 0 & \1-GenerallN-Transition to Ops Plan & N/A & PLN-4862 \\
\hline $\begin{array}{l}\text { Remote-Handled Low-Level Waste } \\
\text { Disposal Facility Preliminary Fire Hazards } \\
\text { Analysis }\end{array}$ & 1 & \1-Genera\\
O-Preliminary FHA & N/A & HAD-474 \\
\hline Commissioning Plan & 0 & 11-General\P-Commissioning Plan & RH-LLW-CP-00001 & N/A \\
\hline
\end{tabular}


Review Comments \& Resolutions

Infrastructure Review Comments \& Resolutions

\begin{tabular}{|l|l|l|l} 
N/A & 12-Infrastructure\_Review Comments \& Resolutions $\$ & N/A & N/A
\end{tabular}

\section{Drawings}

Infrastructure Drawings

|2-Infrastructure\A-Infrastructure Drawings \}

RH LLW-DRAW-0030 - 0194

INL Drawing 788748 788912

\section{Construction Specifications}

Admin Building Construction Specification

Maintenance Building Construction Specification

General Site Construction Specification

Vendor Data Schedules

0

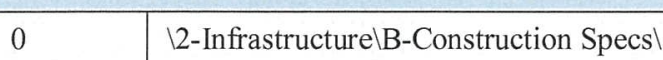

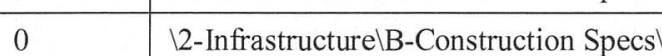

|2-Infrastructure〈B-Construction Specs $\backslash$

|2-Infrastructure $\backslash B-C o n s t r u c t i o n ~ S p e c s \backslash$

Performance Specifications

Admin Building Performance Specification

Maintenance Building Performance

Specification

Fire Sprinkler Performance Specification

Fire Alarm Performance Specification

0

\begin{tabular}{|c|c|c|c|}
\hline 0 & |2-Infrastructure $\backslash C$ - Performance Specs $\backslash$ & RH LLW-SPC-00001 & SPC-1861 \\
\hline 0 & 2-Infrastructure $\backslash C$ - Performance Specs & RH LLW-SPC-00002 & SPC-1862 \\
\hline 0 & |2-Infrastructure \C- Performance Specs $\backslash$ & RH LLW-SPC-00003 & SPC-1863 \\
\hline 0 & 12-Infrastructure $\backslash C$ - Performance Specs $\backslash$ & RH LLW-SPC-00004 & SPC-1864 \\
\hline
\end{tabular}

Design Support Information

Administration/Maintenance Building

Foundation Design

Electrical Design Support Information

Mechanical Design Support Information

Civil Design Calculation

Architectural Design Support Detail

SKM Electrical Design Model Results

0

\begin{tabular}{l|l}
\hline 0 & 12-InfrastructurelD-Design Support Information
\end{tabular}

RH LLW-CALC-00003

\begin{tabular}{l|l}
0 & 12-InfrastructurelD-Design Support Information
\end{tabular}

\begin{tabular}{l|l}
0 & 12-Infrastructure $\backslash D$-Design Support Information
\end{tabular}

\begin{tabular}{l|l}
1 & 12-InfrastructurelD-Design Support Information
\end{tabular}

\begin{tabular}{l|l}
\hline 0 & 12-InfrastructurelD-Design Support Information
\end{tabular}

|2-Infrastructure\D-Design Support Information

\begin{tabular}{|l|l|}
\hline RH LLW-SPC-00006 & SPC-1858 \\
\hline RH LLW-SPC-00007 & SPC-1859 \\
\hline RH LLW-SPC-00008 & SPC-1860 \\
\hline & \\
\hline
\end{tabular}

Miscellaneous

Utilities Tie-in Subsurface Investigation

Report

USQ Evaluation for Utilities Tie-in

Installation

Building Septic System Permit

\begin{tabular}{|l|l|l|l|}
\hline N/A & 2-InfrastructurelE-Misc. & N/A & N/A \\
\hline 0 & 2-InfrastructurelE-Misc. & N/A & $\begin{array}{l}\text { ATR Complex-USQ- } \\
2014-539\end{array}$ \\
\hline N/A & 12-InfrastructurelE-Misc. & N/A & N/A \\
\hline
\end{tabular}


Deliverable

Rev. Folder

Infrastructure Construction Quality

Verification Plans
AREVA Document \#

RH LLW-EIR-00020
BEA Document \#

(if applicable)

PLN-4995

\section{Vault System}

\section{Review Comments \& Resolutions}

\begin{tabular}{|c|c|c|c|c|}
\hline $\begin{array}{l}\text { Vault System Review Comments \& } \\
\text { Resolutions }\end{array}$ & N/A & \3-Vaults \Review Comments \& Resolutions $\backslash$ & N/A & N/A \\
\hline \multicolumn{5}{|l|}{ Drawings } \\
\hline Vault Installation Drawings & varies & |3-Vaults\A-Vault System Drawings $\backslash$ & RH LLW-DRAW-0001 - 0016 & $\begin{array}{l}\text { INL Drawing } 788643- \\
788658\end{array}$ \\
\hline Vault Fabrication Shop Drawings & varies & |3-Vaults\A-Vault System Drawings $\backslash$ & RH LLW-DRAW-0200 - 220 & N/A \\
\hline
\end{tabular}

\section{Construction Specifications}

Vault Construction Specification - Vault

Fabrication

Vault Construction Specification - Vault

Installation

Vendor Data Schedules

2-Infrastructure $\ E-M i s c$.

\begin{tabular}{|c|c|c|c|c|}
\hline Vendor Data Schedules & 1 & |3-Vaults \B-Specifications $\backslash$ & & \\
\hline \multicolumn{5}{|l|}{ Design Support Information } \\
\hline System Design Description & 2 & |3-Vaults\C-Design Support Information\ & N/A & SDD-410 \\
\hline Vault System Structural Design & 2 & |3-Vaults \C-Design Support Information $\backslash$ & RH-LLW-CALC-00001 & ECAR-2810 \\
\hline $\begin{array}{l}\text { Vault System Minimum Reinforcement and } \\
\text { Lifting Lug Design }\end{array}$ & 2 & \3-Vaults\C-Design Support Information \} $&{\text { RH-LLW-CALC-00005 }} &{\text { ECAR-2744 }} \\
{\hline \text { Vault Plug and CVAS Shielding Analysis }} &{2} &{\text { |3-Vaults \C-Design Support Information } \backslash} &{\text { RH LLW-CALC-00006 }} &{\text { ECAR-2747 }} \\
{\hline \multicolumn{5}{|l|}{\text { Concrete Mix Design \& Related Documents }}\text { Concrete Mix Design \& Related Documents }} \\
{\hline \text { Vault Concrete Safety-Related Test Plan }} &{0} &{\text { |3-Vaults \D-Concrete Documents } \backslash} &{\text { RH LLW-TEST-00001 }} &{\text { PLN-4955 }} \\
{\hline \text { Vault Concrete Durability Test Plan }} &{0} &{\mid 3-\text { Vaults } \backslash D \text {-Concrete Documents } \backslash} &{\text { RH LLW-TEST-00002 }} &{\text { PLN-4867 }} \\
{\hline \text { Vault Compliance Test Plan }} &{3} &{\text { \3-Vaults\D-Concrete Documents } \backslash} &{\text { RH LLW-TEST-00003 }} &{\text { PLN-4956 }} \\
{\hline \text { Vault Concrete Mix Design Report: }} &{2} &{\text { |3-Vaults } \backslash D \text {-Concrete Documents } \backslash} &{\text { RH LLW-EIR-00001 }} &{\text { PLN-4953 }} \\
{\hline \begin{array}{l}\text { Vault Concrete Safety-Related Design } \\
\text { Parameters }\end{array}} &{2} &{\text { |3-Vaults } \backslash D \text {-Concrete Documents } \backslash} &{\text { RH LLW-EIR-00013 }} &{\text { PLN-4954 }} \\
{\hline \text { Vault Concrete Selection Report }} &{1} &{\text { |3-Vaults } \backslash D \text {-Concrete Documents } \backslash} &{\text { RH LLW-EIR-00014 }} &{\text { PLN-4952 }} \\
{\hline \begin{array}{l}\text { Vault Hydraulic and Concrete Performance } \\
\text { Analysis }\end{array}} &{\text { N/A }} &{\mid 3 \text {-Vaults } \backslash D \text {-Concrete Documents } \backslash} &{\mathrm{N} / \mathrm{A}} &{\mathrm{N} / \mathrm{A}} \\
$\hline
\end{tabular}

Miscellaneous

\begin{tabular}{|l|l|l|l|}
\hline 2 & 13-Vaults\B-Specifications & RH LLW-SPC-00005 & SPC-1857 \\
\hline 2 & 13-Vaults\B-Specifications & RH LLW-SPC-00014 & SPC-1910 \\
\hline 1 & 13-Vaults \B-Specifications & & \\
\hline
\end{tabular}




\begin{tabular}{|c|c|c|c|c|}
\hline Deliverable & Rev. & Folder & AREVA Document \# & $\begin{array}{l}\text { BEA Document \# } \\
\text { (if applicable) }\end{array}$ \\
\hline Vault Array Summary Table & 1 & |3-Vaults \E-Misc. $\mid$ & RH LLW-EIR-00015 & TEV-2559 \\
\hline $\begin{array}{l}\text { Vault and CVAS Fabrication Quality } \\
\text { Verification Plan }\end{array}$ & 2 & $\mid 3$-Vaults|E-Misc. $\mid$ & RH LLW-EIR-00021 & PLN-4957 \\
\hline Vault Installation Quality Verification Plan & 2 & $\mid 3$-Vaults $\backslash$ E-Misc.| & RH LLW-EIR-00022 & PLN-4994 \\
\hline \multicolumn{5}{|l|}{ Ancillary Equipment } \\
\hline \multicolumn{5}{|l|}{ Review Comments \& Resolutions } \\
\hline $\begin{array}{l}\text { Ancillary Equipment Review Comments \& } \\
\text { Resolutions }\end{array}$ & N/A & $\begin{array}{l}\text { 14-Ancillary Equipment\_Review Comments \& } \\
\text { Resolutions } \\
end{array}$ & N/A & N/A \\
\hline \multicolumn{5}{|l|}{ Drawings } \\
\hline Ancillary Equipment Drawings & varies & \4-Ancillary Equipment\A-Design Drawings \} $&{\text { RH LLW-DRAW-0230 - } 0242} &{\begin{array}{l}\text { INL Drawing } 791350 \text { - } \\
791353\end{array}} \\
{\hline \multicolumn{5}{|l|}{\text { Design Support Information }}\text { Design Support Information }} \\
{\hline \text { Cask Seismic Stability Evaluation }} &{1} &{\text { 14-Ancillary Equipment|B-Design Support Information \} } &{\text { RH LLW-CALC-00013 }} &{\text { ECAR-2878 }} \\
{\hline \text { Manitowoc Crane Report }} &{0} &{\text { |4-Ancillary Equipment|C-Crane Report| }} &{\text { N/A }} &{\text { TEV-2339 }} \\
\hline\end{array}$
\end{tabular}

